PRIFYSGOL

glyndŵr

Glyndŵr University

Glyndŵr University Research Online

Theology

Theology

$1-1-2010$

\title{
Karl Popper and Pentecostal Historiography
}

William K. Kay

GlyndwrUniversity, w.kay@glyndwr.ac.uk

Follow this and additional works at: http://epubs.glyndwr.ac.uk/theo

Part of the Religious Thought, Theology and Philosophy of Religion Commons

This is the author's post print version after refereeing. 'This article was published in Pneuma, in 2010, which is the journal of the Society for Pentecostal Studies. The published article is available at http://www.ingentaconnect.com

\section{Recommended Citation}

Kay, W. K. (2010) 'Karl Popper and Pentecostal Historiography' Pneuma, 32(1), 5-15(11)

This Article is brought to you for free and open access by the Theology at Glyndŵr University Research Online. It has been accepted for inclusion in Theology by an authorized administrator of Glyndŵr University Research Online. For more information, please contact d.jepson@glyndwr.ac.uk. 


\title{
Karl Popper and Pentecostal Historiography
}

William K Kay, Professor of Theology

Email: w.kay@glyndwr.ac.uk

\begin{abstract}
Karl Popper argued that science proceeds not by induction but by offering explanatory theories which scientists then attempt to falsify. What cannot be falsified, falls outside the realm of science. In applying his ideas to the writing of history Popper was particularly scathing about Marxist predictions of future historical development. But he did believe history could be written by looking at the situations historical figures found themselves in and the problems they attempted to solve. Pentecostal historiography has been divided into four main types: the providential, the historical roots, the multicultural and the functional. When each of these types is analysed and judged against Popper's strictures against induction, we find, among other things, that the unfashionable providential account need not be ruled out.
\end{abstract}

\section{Keywords}

Popper, Pentecostalism, historiography, Providence

\section{Introduction}

Karl Popper (1902-94) is probably the $20^{\text {th }}$ century's most influential philosopher of science. His work is extensive and this paper concentrates on two aspects of it. First is his discussion of the scientific method and the history of science. His view of science is determined by the principle 
of falsification. In essence he argued that scientific theories are those which can be falsified, and that good scientific theories are those which explain a wider range of phenomena than less good scientific theories. ${ }^{1}$ Absolute knowledge within science is unattainable but falsification provides the means by which greater degrees of certainty can be approached. In essence, the scientist tries to disprove his or her own theories. ${ }^{2}$ The more stringent these attempts are and the more decisively they fail, the greater the confidence that can be given to the theories.

His discussion of falsification arises from his reflection upon the problem of induction. The old notion of science stemming from Bacon was that large general laws could be abstracted from numerous instances. ${ }^{3}$ The problem with induction within science is, as Popper pointed out, that a single counter-instance can invalidate thousands of instances and we never know whether a counter-instance might be just around the corner. We might predict that all crows are black because we have seen 10,000 black crows but when, quite unexpectedly, we meet an albino crow, the law which states that all crows are black is immediately exploded. Falsification as the antidote to the flaws of induction was tenaciously defended by Popper throughout his life once he had 'solved the problem'.

By applying falsification both to the defining characteristics of science and to the method of science, Popper was in a position to rewrite scientific history. All those disciplines which fell outside his method (like alchemy) could simply be ignored while all those disciplines which

\footnotetext{
${ }^{1}$ In Popper's words 'theories are essentially argumentative systems of statements' in K.R. Popper, “Autobiography", in P. A. Schlipp (ed) The Philosophy of Karl Popper (La Salle, IL: Open Court, 1974), p. 61.

${ }^{2}$ P. B. Medawar, Induction and Intuition in Scientific Thought (Philadelphia, American Philosophical Society, 1969).

${ }^{3}$ F. Bacon Novum Organon, first published in 1620. A more recent re-issue is edited by Lisa Jardine and Michael Silverthorne, The New Organon (Cambridge: Cambridge University Press, 2000).
} 
were testable and generated falsifiable explanatory theories could be included. This allowed him to trace the story of scientific ideas and, in a paradigmatic example, demonstrate how Newtonian physics was properly replaced by Einsteinian physics. ${ }^{4}$ Both types of physics explain the same range of phenomena and both can be subjected to falsification but the theories of Einstein also explain additional phenomena and deal with anomalies that had over time crept into the Newtonian account.

Second, Popper dealt with the development of society. His particular target here was the propagation of ideologically-driven grand theories of society, most particularly communism, which rested upon no proper empirical basis and which sought to bring vast changes into play without any attempt at falsification or small-scale implementation. Marxism, and indeed fascism of which Popper himself was a victim, developed totalising explanations of society which not only encompassed social and economic propositions but also sought to control the functions of the state in regard to science, history, philosophy and other intellectual activities. Any general history influenced by Popper will give no ground to Marxist or fascist 'laws' of social development. Moreover, it will ardently contest the notion of 'false consciousness', a preemptive argumentative tactic used by Marxists to dismiss the theorisation of any opposing social group. 5

\section{Popperian history writing}

If we approach this issue through Popper's work, then we find his fullest discussion of history in The Poverty of Historicism (1944) and The Open Society and its Enemies (1945). At the time

\footnotetext{
${ }_{5}^{4}$ E.g. in Karl R. Popper, The Logic of Scientific Discovery (London: Hutchinson \& Co, 1965).

${ }^{5}$ See an example of this bitter debate discussed in, D. Frisby, "The Popper-Adorno Controversy: the Methodological Dispute in German Sociology”, Philosophy of the Social Sciences. 2 (1972), pp. 105-119.
} 
when he wrote, 'historicism' was attractive to German historians. This was the attempt by scientifically-minded historians to provide an account of the past that could be used to predict the future. The idea was that any complete theory of societal development that could be substantiated from historical examples could then be projected forward to future events. Actually, the discussion was more subtle than this since Marxists, who were the chief propagators of this view, agreed that within definable epochs human decision-making could adjust what would otherwise be completely predetermined. They understood human beings could learn from history and deliberately avoid repeating earlier patterns of events. Yet, even though human agents might be able to influence the course of individual epochs, the actual sequence of the epochs was beyond human control and would follow the 'iron' laws of history. ${ }^{6}$

Popper's detestation of historicism ran deep but his refutation of it was measured and logical. He argued that the course of human history depends upon the development of human knowledge and that, in principle and by definition, new knowledge is not knowable in advance. ${ }^{7}$ If it were knowable, it would not be new. It is therefore impossible for human history to be predicted or reduced to a single explanatory theory. By contrast, scientific explanatory theories earned credibility precisely in this way. They predicted critical events - critical in the sense that, if they failed to occur, the theories could be shown to be wrong. In many situations these events needed to be repeatable to allow proper scrutiny. Since historical events could not be manipulated and forced to repeat themselves, the testing of historical theories was well-nigh impossible. The same kind of considerations applied to the theory of evolution. This is why Popper categorised

\footnotetext{
${ }^{6}$ Alan Donagan, "Popper's examination of historicism”, in P. A. Schlipp (ed) The Philosophy of Karl Popper (La Salle, IL: Open Court, 1974), p. 913.

${ }^{7}$ Where knowledge is a 'system of statements - theories submitted for discussion' in Karl R. Popper

“Autobiography”, in P. A. Schlipp (ed) The Philosophy of Karl Popper (La Salle, IL: Open Court, 1974), p. 68.
} 
the theory of evolution as a metaphysical theory rather than a scientific one. It was a theory that created a framework in which science could be carried out but it was not in itself scientific in the sense of being open to falsification.

Yet it would be a mistake to think that Popper denied the usefulness of historical theories. He fully saw that the historian must select from the multitude of details a path through the jungle of possible interpretations so as to present a coherent narrative. What he objected to was the classification of historical theories as historical laws. He appreciated that historicism arose out of the reaction against a naive account of history as being driven by the commanding actions of kings and generals. His answer to the difficulty of writing history was to propose that historians must introduce a 'preconceived selective point of view' to allow a choice to be made of all the material available. ${ }^{8}$ This selectivity does indeed function 'in some ways analogous to those of theories in science' which explains why historical generalisations have sometimes been misunderstood as historical laws. ${ }^{9}$ So the historian needs to inform the reader of the point of view that determines the selection and interpretation of facts and then to ignore all those other facts that have no bearing on the line being pursued.

In dealing with the historical actions of individuals there is room for a detailed account of the 'logic of situations' to which sociology can contribute its analysis. The logic of the situation illuminates the choices available to individuals and this, together with an understanding of the functioning of social institutions, can allow models to be constructed that historians may use for

\footnotetext{
${ }^{8}$ Karl R. Popper, The Poverty of Historicism (London: Routledge \& Kegan Paul, 1957), p. 150.

${ }^{9}$ Ibid p. 151.
} 
the purpose of explanation. ${ }^{10}$ Institutions bulk large in the proposal that Popper gives since institutions are collective expressions of human values and rationality. It is through the examination of ideas by means of institutional scrutiny that rationality advances knowledge. The public character of science embodied in its institutions preserves the objectivity of science, where objectivity is seen as inter-subjective agreement reached by a rational critique. A theory of progress that focuses upon institutions is consequently highly desirable.

The notion of the logic of situations is compatible with Popper's notion of scientific (and indeed artistic) progress being made by the solving of problems. Neither science nor art is a matter of self-expression nor of random discoveries. Rather, science and art progress by using the technical means at their disposal to solve the problems of the world in the tradition left behind by the intellectual efforts of their predecessors. ${ }^{11}$ In its own way history writing may also be seen as the attempt to solve historical problems even if, as indicated above, it is also written with a view to satisfying the interests of the individual historian. As we shall see, such interests impinge upon an account of the world as a place where scientifically described regularities occur. Can a religious historian use theories that run counter to scientific theories?

\section{Other history writing}

Before answering the Popperian questions, we need to take a short digression through other approaches to history writing.

\footnotetext{
${ }^{10}$ Ibid. p. 149. See also Langdon Gilkey, "Problems and Possibilities of Theological Models: responding to David Klem and William Klink", Zygon 38: 3 (September 2003), pp. 529-534.

11 'Organisms are problem-solving rather than end-pursuing' in Karl R. Popper, "Autobiography”, in P. A. Schlipp (ed) The Philosophy of Karl Popper (La Salle, IL: Open Court, 1974) p. 142.
} 
In a discussion of historiography at the $20^{\text {th }}$ annual SPS meeting in Dallas, Texas, in 1990, I outlined the problems facing the historian of Pentecostalism. ${ }^{12}$ In short, nearly all the significant leaders and preachers involved in the Pentecostal movement from the beginning have entertained a strong belief in Providence. They believed not only that their own lives were shaped by God, but also that the human race as a whole was moving in a direction consonant with a biblical eschatological scheme. The historian of Pentecostalism is placed in a position where he or she must either attempt to remain uncommitted about the miraculous and the workings of Providence or else side with the participants in the narration. ${ }^{13}$ I showed how some Pentecostal historians managed to explain what the participants believed about healing and answered prayer without themselves revealing whether they thought such beliefs were justified. In these instances the authorial voice of the historian remains studiedly neutral. In other instances the Pentecostal historian comes off the fence to say that this or that event was indeed an answer to prayer, an act of God, and so on. ${ }^{14}$ Yet, even when the Pentecostal historian attempts to remain neutral, the selection of the material that is presented to the reader may well carry a covert message. The overarching point here is that modern historiographical methods are inhospitable to accounts of the miraculous; this generates an inevitable tension.

In an article in Pneuma in 1997 Augustus Cerillo offered four different approaches to the history of American Pentecostal origins. The first was the providential approach illustrated in such books as Carl Brumback's Suddenly... From Heaven: a history of the Assemblies of God (1961).

\footnotetext{
${ }^{12}$ William K. Kay, "Three Generations on: the methodology of Pentecostal history", Twentieth Annual Meeting of the Society for Pentecostal Studies, November 8-10, 1990, and later published in the EPTA Bulletin, X:1 \& 2, (1992), pp. 58-70.

${ }^{13}$ E.g. Edith L. Blumhofer, The Assemblies of God: A chapter in the story of American Pentecostalism, 2 vols. (Springfield: Gospel Publishing House, 1989).

${ }^{14}$ E.g. Charles W. Conn, Like a Mighty Army: A History of the Church of God, (Tennessee: Pathway Press, 1977). And, sometimes, Gary B. McGee, This Gospel Shall Be Preached 2 vols. (Springfield: Gospel Publishing House, 1986-1989).
} 
The second was the historical roots approach which followed Wesleyan and holiness lines of enquiry and revealed the complicated institutional, theological and experiential strands that ultimately eventuated in $20^{\text {th }}$ century Pentecostalism. The third was the multicultural approach that sought to redefine Pentecostalism as a multicultural phenomenon springing from African and Afro-American impulses within American culture and arguing that only by understanding the partnerships and contributions of African contributors can Pentecostalism be properly comprehended. The fourth was a functional approach which saw the function of Pentecostalism as a means by which psychologically maladjusted migrants in the new American cities recreated the religious habitus of their origins or in other ways found in religion a psychological antidote to their own disorientation and marginalisation. In the Cerillo's view each of the approaches helps 'illuminate the broad contours that shaped the new Pentecostal movement'.

These approaches by no means exhaust the possibilities. More recent accounts of history as an academic discipline show that there are those who simply want to get on with the job of writing history without plunging into epistemological disputes. ${ }^{15}$ They want to steer a course between unbridled subjectivity and impossible objectivity -- whatever these terms exactly mean. Others want to improve standards of logic and argumentation within history and to 'refuse epistemological doubt in favour of analytical rigour'. Yet others want to shake off postmodernist doubts over the nature of evidence and to re-engage earlier explanatory discourses. If

\footnotetext{
${ }^{15}$ Penelope Corfield, "The state of history: review article", Journal of Contemporary History, 36:1, (2001) pp. 153161 provides an excellent overview from which this paragraph is taken. The article covers Miles Fairburn, Social History: problems, strategies and methods (London: Macmillan, 1999); Brian Fay, Philip Pomper and Richard T Vann, eds, History and Theory: contemporary readings (Blackwell: Oxford, 1998); Elizabeth Fox-Genovese and Elisabeth Lasch-Quinn, eds, Reconstructing History: the emergency of a new historical society (New York: Routledge, 1999); Anna Green and Kathleen Troup, eds, The Houses of History: a critical reader in twentiethcentury history and theory (Manchester: Manchester University Press, 1999); Ludmilla Jordanova, History in Practice (London: Arnold, 2000); S.H. Rigby Marxism and History: a critical introduction, $2^{\text {nd }}$ edn. (Manchester: Manchester University Press, 1998).
} 
some historians focus on social, cultural, gender, sexual, familial and 'identity' history, then so be it. Yet others wish to turn away from empiricism towards theory, particularly literary theory that embraces self-reflexiveness and a whole repertoire of rhetorical devices like irony and comedy. Indeed such history sees itself as being closer to literature than science. This only underlies the debate between postmoderns who are sceptical about the possibility of any secure knowledge and those who feel such scepticism may subvert social coherence or the profession of history itself.

In a large-scale and recent survey of historiography, John Burrow has shown that the writing of history as a genre is part of Western culture as a whole and has been highly influential over the years as a 'receptacle for the concerns of that culture'. This is especially so as European societies have attached immense importance to versions of their pasts and sought in historical writings for legendary, heroic, tragic and pathetic motifs as well as for inspiring and military rhetoric. ${ }^{16}$ History writing has been concerned with the distinctness of European civilisation contrasted with the empires of Asia, with national identity and national liberation, with republican virtue (drawing on Roman precedent), with giving a voice to oppressed minorities and with tracing the course of the development of constitutions and nation states.

Historians have brought to their voluminous writings the philosophical and religious predispositions that animated their own lives. Burrow, however, is not dismissive of historians who believed in Providence like, for example, Eusebius and Bede. Eusebius, writing after the conversion of Constantine, was concerned to establish doctrinal orthodoxy and, for this reason, took trouble to quote his sources 'with the ironic result of bringing his practice closer to that of

\footnotetext{
${ }^{16}$ John Burrow, A History of Histories, (London: Allen Lane, 2007), p. xvii.
} 
modern historians, just as the religious controversies of the Reformation were later to do' ${ }^{17}$ Bede, writing with a didactic purpose of encouraging good conduct by recording notable examples of goodness and wickedness, found his belief in Providence leading him to discuss political situations in a way analogous to that taken by the writers of the books of Samuel and Kings on whom he had written an earlier commentary. In other words belief in Providence led historians to value and analyse the activities of individuals in a way that was quite distinct from those historians whose motivations were prompted by abstract secular theories. Moreover, belief in Providence was perfectly compatible with a belief in the 'Whig interpretation of history', that is, the interpretation of history that saw it as proceeding upon a gentle upward path of human enlightenment and progress. In addition, as Burrow points out, histories of science were intrinsically Whig in their orientation since science is always seen as getting better and better. ${ }^{18}$

\section{Practical and theoretical conclusions}

In practical terms: the Pentecostal historian who takes heed to Popper's ideas will avoid inductive reasoning. This means that the Pentecostal historian who has a particular theory to propose will not attempt to prove his or her theory by multiple instances. This would be to stray too near to the process of induction. Yet, in many histories this is what tends to happen. The historian looks for illustrations to support a theory and ignores all the counter-illustrations that might falsify the theory. When the book is closed, the reader is left with the impression that the theory has been amply substantiated.

\footnotetext{
${ }^{17}$ Ibid. p. 191.

${ }^{18}$ Ibid, p. 474.
} 
It is evident that theology is a rich storehouse of abstract notions and that these can function for the Pentecostal historian as the source of numerous theories. The most comprehensive and simple is that of Providence but this is a theory which is not susceptible to falsification since it is always possible to attribute a disaster to hidden sinfulness. Although Pentecostal historians will instinctively attribute the worldwide success of Pentecostalism within the 20th century to providential activity, it is also clear that there are parts of the world where Pentecostal doctrine and Christian life have failed to penetrate and triumph. However, following Popper there is, as we have said, nothing wrong in using Providence as an organising framework, and Pentecostal historians should not be ashamed of doing so given the compatibility of providential impulses with Whig ideas of progress, including scientific progress.

The three other types of history-writing outlined by Cerillo, and used by Pentecostal historians, can be further commented on in the light of Popper's ideas. Each of these types can be analysed so as to unpack its conception more precisely. The historical roots approach depends, first, on the identification of the phenomenon, whether it be the formation of Pentecostalism as a whole or Pentecostal denominations or a movement allied to Pentecostalism like the charismatic movement, and the analysis of this phenomenon into its constituent elements. Once the analysis has taken place, then, in the second step, the constituent elements need to be tracked back in time. The elements may be ideas or institutional forms or even persisting economic relations and the presumption of the historical roots approach is that every element can be accounted for by prior activity: that the past might influence the present but that the present can have no causative purchase on the past. The process of tracking back is the key concern of the historical roots approach since it aims to identify precursors, antecedents and prototypes of what subsequently 
came to full fruition. The notion is that the tracking back process might take place through the transmission of doctrines, by contact between people through face-to-face meetings or through the publication or letters or by more indirect and subtle influences related to the existence of common conditions between the past and the event that is being examined. Third, the historical narrative can be constructed, but now told forwards beginning in the past and working towards the event whose roots have been traced. The historical roots approach therefore displays the characteristics of a detective story where the author knows the murderer from the beginning but the reader does not. ${ }^{19}$

The multicultural approach uses culture as a superordinate category. It needs to be pointed out that any superordinate category could be used and that culture, which can be a broad and illdefined concept associated with the way of life of a definable human group, is particularly appropriate for this sort of exercise. The existence of culture is rarely denied and the term is broad enough to include subcultures, high arts (like opera and the leisure pursuits of the educated and wealthy) or lifestyle choices and habits (like slang, characteristic modes of dress, food preferences). But it can also include low culture encompassing the leisure pursuits of the less well educated and poorer members of society (as, in Britain, greyhound racing as opposed to horse racing, eating fish and chips as opposed to fine dining, and so on). The first step in any multicultural history is to select the social and ethnic members of the group that is going to be the focus of the historian's attention. Thus a cultural method might include simply black musicians rather than the entirety of Afro-Americans but it could equally include women, children, disabled people, converts from Catholicism or any social group with describable

\footnotetext{
${ }^{19}$ Donald W. Dayton, Theological Roots of Pentecostalism (Peabody, MA: Hendrickson, 1987) is the most obvious and distinguished example.
} 
attitudes and lifestyles. Indeed, it immediately comes apparent that culture, being such a broad and slippery concept, is in danger of attracting misleading generalisations. Nevertheless, the second step is to look for traces of the culture of the particular group that has been selected in the Pentecostal movement as a whole with, as the third step, the intention of highlighting the special contribution of the group that has been selected. And, as a fourth step, the process then proceeds in the same way as the historical roots method by tracking back in time to see the earlier contribution of the selected group within emerging Pentecostalism.

The functional approach begins by looking at the functions of Pentecostalism, either social or psychological. $^{20}$ These functions may involve benefits that are peripheral to its stated theology. Pentecostalism may function to raise the educational level of disadvantaged children, to provide credit networks for the poor, to organise factory workers, to provide a strong rationale against wasting money on excessive alcohol or drugs or to provide an answer to existential angst and meaning for first-generation migrant blue-collar workers, and any number of other possibilities. Once the functions of Pentecostal and have been identified to the historian's satisfaction, all that is necessary is to find a group for which the functions are desirable and then to tell the story Pentecostalism in the light of this group. The classic account here is Vision of the Disinherited which effectively explains the rise Pentecostalism through its social and psychological utility rather than by any supernatural or providential causation. ${ }^{21}$

\footnotetext{
${ }^{20}$ Some of these are outlined by Kilian McDonnell, Charismatic Renewal and the Churches (New York: Seabury Press, 1976, p. 20f) which instances, among other writers, Anton T. Boisen, Religion in Crisis and Custom: a sociological and psychological study (New York: Harper \& Row, 1945).

${ }^{21}$ Robert M. Anderson, Vision of the Disinherited (Oxford: OUP, 1979).
} 
An application of Popper's line of thought to the historical roots approach would at least note that there was a non-inductive and non-predictive norm within this type of history writing, especially as its concern was to trace lines of influence through human or institutional agencies rather than as a consequence of grand historical theories. The multicultural approach is similarly non-inductive and non-predictive. It is the functional approach that tends to be inductive in the sense that it looks for multiple instances of the particular function that it has identified as being powerfully explanatory of Pentecostal success. Vision of the Disinherited presumes that it is the provision of religious meaning for many erstwhile farm workers at the end of the 19th century that is the particular contribution of Pentecostalism. Once this presumption is made, then instances have to be found to support the case. Once this presumption is made, also, some type of prediction may arise. Even so, the functional approach may, despite itself, attract credence resulting from its implicit imaginative sympathy. This is because the approach depends upon identifying a lasting psychological need that human beings today can attribute to human beings a hundred years ago. Human beings today can appreciate the need for meaning and purpose at a time of social change, the need for the protection of the poor, and so on, and thus despite its focus on functionality the approach also builds upon the notion of unchanging human nature.

In theoretical terms: we return to our original point of departure. While it is clear that the roots approach, the multicultural approach and the functional approach would be able to operate without any substantial reference to miracles, answered prayer, prophecy, and other divine interventions, it is equally clear that the providential approach is almost bound to make reference to these phenomena. And, if the providential approach does this, is it effectively running counter to the great weight of scientific theory and thought and perversely allowing unfalsifiable 
statements and falsified worldviews into an historical narrative? While it would be perverse to tell the history of science from the perspective of a narrator who denied the validity of scientific methods, it is not perverse to permit an historian who has an interest in a religion expressing this through historical models that make use of the beliefs and practices of religious actors within the historical process. For the religious actor, the logic of the situation may be quite different from the logic of the same situation perceived by a non-religious actor. In this way Popper's case does not preclude the writing of history from a religious point of view. Thus, Popper, as we have said, will direct attention to the human actors of history - whether religious or not - and the predicaments in which they found themselves and the problems they solved.

In short, Popper gives Pentecostal historians at least five things: (a) according to my deductions he does not, as others do, rule out Providence (b) he warns against a method that is simply the collection of examples and the ignoring or suppression of counter-examples (c) he warns against trying to predict the future from the past and (d) he would perhaps only have reservations about the functional approach discussed above. Lastly, (e) he encourages us to view individuals as making important decisions to extricate themselves from predicaments and in this way discourages us from seeing historical development as being driven by abstract forces.

\section{Bibliography}

Anderson, Robert M., Vision of the Disinherited (Oxford: OUP, 1979).

Bacon, Francis., Novum Organon, first published in 1620. A more recent re-issue is edited by

Lisa Jardine and Michael Silverthorne, The New Organon (Cambridge: Cambridge University Press, 2000). 
Blumhofer, Edith L. The Assemblies of God: A Chapter in the Story of American Pentecostalism, 2 vols. (Springfield: Gospel Publishing House, 1989).

Burrow John, A History of Histories, (London: Allen Lane, 2007).

Corfield, Penelope, "The state of history: review article", Journal of Contemporary History, 36:1, (2001) pp. 153-161.

Conn, Charles W., Like a Mighty Army: A History of the Church of God, (Tennessee: Pathway Press, 1977).

Dayton, Donald W., Theological Roots of Pentecostalism (Peabody, Mass: Hendrickson, 1987)

Donagan, Alan, “Popper's examination of historicism”, in P.A. Schlipp (ed) The Philosophy of Karl Popper (La Salle, IL: Open Court, 1974).

Fairburn, M. Social History: problems, strategies and methods (London: Macmillan, 1999).

Fay, Brian, Philip Pomper and Richard T Vann, eds, History and Theory: contemporary readings (Blackwell: Oxford, 1998).

Fox-Genovese, Elizabeth and Elisabeth Lasch-Quinn, eds, Reconstructing History: the emergency of a new historical society (New York: Routledge, 1999).

Frisby, D., "The Popper-Adorno Controversy: the Methodological Dispute in German Sociology", Philosophy of the Social Sciences, 2 (1972), pp. 105-119.

Green, Anna and Kathleen Troup, eds, The Houses of History: a critical reader in twentiethcentury history and theory (Manchester: Manchester University Press, 1999).

Jordanova, Ludmilla, History in Practice (London: Arnold, 2000)

Kay, William K., "Three Generations on: the methodology of Pentecostal history”, Twentieth Annual Meeting of the Society for Pentecostal Studies, November 8-10, 1990, and later 
William K Kay The Science of History

published in the EPTA Bulletin: European Pentecostal Theological Association, X:1 \& 2, (1992), pp. 58-70.

McDonnell, Kilian, Charismatic Renewal and the Churches (New York: Seabury Press, 1976).

McGee, Gary B., This Gospel Shall Be Preached 2 vols. (Springfield: Gospel Publishing House, 1986-1989).

Medawar, Peter B., Induction and Intuition in Scientific Thought (Philadelphia: American Philosophical Society, 1969).

Popper, Karl R., The Poverty of Historicism (London: Routledge \& Kegan Paul, 1957).

—, The Logic of Scientific Discovery (London: Hutchinson \& Co, 1965).

—, "Autobiography", in P.A. Schlipp (ed), The Philosophy of Karl Popper (La Salle, IL: Open Court, 1974).

Rigby, S.H. Marxism and History: a critical introduction, $2^{\text {nd }}$ edn. (Manchester: Manchester University Press, 1998). 